\title{
Innflutt fersk matvæli og sýkingaráhætta fyrir menn
}

Karl G. Kristinsson ${ }^{1,2}$ læknir, Franklín Georgsson ${ }^{2,3}$ matvæla- og örverufræðingur

\section{ÁGRIP}

Aðgangur að öruggum matvælum er hluti af forréttindum Íslendinga. Hratt vaxandi sýklalyfjaónæmi, sem meðal annars er tengt verksmiðjubúum og mikilli sýklalyfjanotkun í landbúnaði, er ein helsta ógn við lýðheilsu mannkyns. Vaxandi verslun með matvæli á milli landa og heimsálfa auðveldar dreifingu sýkla og sýklalyfjaónæmis um heiminn. Íslenskur landbúnaður og landbúnaðarafurðir hafa sérstöðu vegna einangrunar landsins og smæðar.

Eftir umfangsmiklar aðgerðir til að draga úr útbreiðslu Campylobacter og Salmonella á kjúklingabúum er nýgengi Campylobactersýkinga orðið um 17-43/100.000 íbúa, par af helmingurinn af innlendum uppruna, og Salmonellusýkinga 10-15/100.000, og par af smitast flestir í útlöndum. Enterohaemorrhagic E. coli (EHEC) hefur ekki fundist í íslenskum naut- gripum og kemur lágt nýgengi (að jafnaði 0-0,6/100.000) pví ekki á óvart. Nýleg hópsýking af völdum fjölónæms EHEC-stofns var rakin til innflutts mengaðs salats. Sýklalyfjanotkun i íslenskum landbúnaði er ein sú lægsta sem pekkist í Evrópu og fágætt er að innlent smit af völdum Salmonella og Campylobacter sé af völdum sýklalyfjaónæmra stofna. Karbapenemasamyndandi Enterobacteriaceae hafa enn ekki fundist á Íslandi.

Lítil notkun sýklalyfja í íslenskum landbúnaði ásamt aðhaldsaðgerðum til að draga úr útbreiðslu Campylobacter og Salmonella hafa borið mikinn árangur. Almenningur parf að vera meðvitaður um mikilvægi uppruna matvæla og að íslenskar landbúnaðarafurðir hafa enn sérstöðu með tilliti til smithættu.
${ }^{1}$ Sýklafræðideild Landspítala, ${ }^{2}$ Háskóla Íslands, ${ }^{3}$ MATÍS

Fyrirspurnir: Karl G. Kristinsson karl@landspitali.is

Greinin barst 31. desember 2014 , sampykkt til birtingar

7. maí 2015.

Höfundar hafa útfyllt eyðublað̃ um hagsmunatengsl.

\section{Inngangur}

Aðgangur að öruggum matvælum og hreinu vatni er ekki sjálfgefinn. Fjölgun íbúa jarðarinnar er hröð og hefur peim fjölgað úr premur milljörðum árið 1960 í rúmlega 7 milljarða í dag. Til að anna eftirspurn eftir matvælum og geta boðið ódýrari matvæli hefur verksmiðjubúskapur í auknum mæli tekið við af hefðbundnum búskap. Worldwatch Institute áætlaði að árið 2006 væru 74\% kjúklinga, 43\% nautgripa, 50\% svína og $68 \%$ eggja í heiminum framleidd á pann hátt. Kjötframleiðsla í heiminum næstum tvöfaldaðist á árunum 19802004 og vöxturinn tengdist aðallega verksmiðjubúskap í próunarlöndunum par sem búskapurinn hefur jafnframt verið að flytjast úr dreifbýli í péttbýli. Aðstæður á verksmiðjubúum eru ákjósanlegar fyrir útbreiðslu sýkla og getur verið erfitt að koma í veg fyrir pá próun. ${ }^{1}$ Verksmiðjubúskap fylgir einnig verulega aukin mengun umhverfis og til að auka framleiðslugetu og koma í veg fyrir afföll vegna smitsjúkdóma er sýklalyfjum gjarnan bætt í fóður dýranna. Petta skapar kjöraðstæður fyrir próun sýklalyfjaónæmis bæði hjá bakteríum í dýrunum sjálfum og í umhverfi peirra. ${ }^{2}$ Péttbýli dýra og manna hefur víða skapað umhverfi par sem próast hafa fjölónæmar bakteríur. Hópsýkingar af völdum fjölónæmra baktería verða sífellt algengari um leið og verslun með matvæli á milli landa og heimsálfa vex og gerir erfitt og oft ómögulegt að rekja uppruna matvælanna. ${ }^{3}$ Pessi vandi hefur pví farið vaxandi prátt fyrir að kröfur um rekjanleika og merkingar hafi aukist. Ef neytandinn veit ekki um uppruna matvælanna er ómögulegt að geta sér til um líkurnar á pví hvort pau séu menguð af sýklalyfjum, fjölónæmum bakteríum og/eða sjúkdómsvaldandi örverum.

Íslenskur landbúnaður hefur haft sérstöðu vegna einangrunar landsins, veðurfars og smæðar. Á sama hátt er sjúkdómastaða íslenskra búfjárstofna einstök og hefur pess vegna verið lögð áhersla á að flytja sem allra minnst af hráum, ómeðhöndluðum dýraafurðum til landsins. Með lögum nr. 143/2009 var matvælalöggjöf Evrópusambandsins innleidd í íslensk lög (reglugerð 102/2010 um gildistöku reglugerðar (EB) nr. 178/2002). Prátt fyrir innleiðinguna, sem tók gildi 1 . nóvember 2011, er áfram óheimilt að flytja inn lifandi dýr og hráar dýraafurðir til landsins nema með undanpágu ráðherra. Núverandi reglur um innflutning á hráum dýraafurðum eru í reglugerð nr. 448/2012 um varnir gegn pví að dýrasjúkdómar og sýktar afurðir berist til landsins, sem byggir á lögunum nr. 25/1993. Undanfarið hefur verið talsverður prýstingur á íslensk stjórnvöld að rýmka reglurnar og heimila mun meiri innflutning á ferskum matvælum. Samkvæmt Evrópsku löggjöfinni er óheimilt að banna innflutning á fersku kjötmeti frá öðrum ríkjum sambandsins nema sýnt sé fram á með vísindalegum rökum að innfluttar afurðir geti ógnað öryggi neytenda mun meira en sambærilegar innlendar vörur. Getur innflutningur á fersku kjötmeti til Íslands ógnað öryggi neytenda? Рað er mikilvægt að íslensk stjórnvöld og íslenskir neytendur geri sér grein fyrir mismunandi áhættu af sýkingum frá hráum matvælum. Markmið 
pessarar greinar er að rekja birtar og óbirtar niðurstöður sem varpað geta skýrara ljósi á pessa áhættu.

\section{Sýkingaráhætta}

Aukin sýkingaráhætta af innfluttum matvælum er pegar meiri líkur eru á smiti af neyslu innfluttra en innlendra matvæla. Рað pýðir jafnframt að menn eru í meiri áhættu af pví að sýkjast af umræddum sýklum pegar peir ferðast til útlanda en pegar peir dvelja á Íslandi og neyta innlendra matvæla. Petta getur verið vegna pess að tilteknir sýklar finnist ekki á Íslandi, eða að tilteknir sýklar finnist sjaldnar eða í minna magni í íslenskum dýrum og matvælum, heldur en í erlendum.

Peir sýklar sem geta sýkt bæði menn og dýr valda svokölluðum súnum (zoonosis). Allir flokkar örvera (bakteríur, sveppir, veirur, príon, ormar og frumdýr) geta sýkt bæði menn og dýr og af peim um pað bil 1400 tegundum örvera sem geta sýkt menn, geta um $60 \%$ sýkt bæði menn og dýr. ${ }^{4,5}$ Margir pessara sýkla eru mjög sjaldgæfir og ekki líklegir til að berast til Íslands. Aðrir eru bæði algengir og líklegir til að geta borist með ferskum matvælum til landsins. Af peim eru helstir bakteríurnar Campylobacter, Salmonella, Escherichia coli og Staphylococcus aureus og hafa peir pví verið valdir til nánari umfjöllunar í pessari grein. Vegna peirrar ógnar sem stafar af sívaxandi sýklalyfjaónæmi, fær pað einnig sérstaka umfjöllun. Rétt er pó að muna eftir lifrarbólguveiru A og Toxoplasma gondii sem geta einnig borist með matvælum og eru tiltölulega sjaldgæf hérlendis, svo og Trichinella spiralis sem ekki er landlæg á Íslandi.

\section{Campylobacter spp.}

Campylobacter, ein algengasta orsök niðurgangs af völdum baktería í heiminum, finnst í eðlilegri örveruflóru (í pörmum) fjölmargra dýra, svo sem nautgripa, kinda, svína, geita, hunda, katta, nagdýra og fugla. ${ }^{6}$ Við slátrun dýra til manneldis er pess sérstaklega gætt að parmainnihald mengi ekki kjötið eða pann hluta sem ætlaður er til neyslu. Við slátrun stórgripa er petta lítið vandamál, en stórt við slátrun kjúklinga par sem nánast er útilokað að slátra alifuglum í tæknivæddum sláturhúsum án saur/gormengunar afurðarinnar.

Salmonella hópsýkingar tengdar alifuglum urðu árið 1979 til pess að bannað var að selja ferska kjúklinga á Íslandi. Tilraunir til að útrýma Salmonella í kjúklingum hófust 1992. Tekin voru sýni frá kjúklingahópum sem fóru til slátrunar, og ef peir voru lausir við Salmonellu mátti slátra peim og selja til neytenda, en ef ekki var peim fargað. Á sama tíma var öll umhirða á búunum bætt og eftirlit aukið. Árangurinn var slíkur að bændur fengu að nýju leyfi til að selja ferska kjúklinga haustið 1995. Í kjölfarið jókst sala og neysla ferskra kjúklinga mjög mikið.

Pegar fólk greinist með Salmonella eða Campylobacter sýkingu á Íslandi afla læknar sýklafræðideildar Landspítalans upplýsinga um líklegan uppruna smitsins ef um innlent smit er að ræða og hvert sé líklegt upprunaland ef um erlent smit er að ræða. Árin 1998 og 1999 fjölgaði innlendum Campylobactersýkingum í mönnum margfalt (mynd 1) og varð nýgengi per 100.000 íbúa næstum 160, sem er með pví hæsta sem pá var skráð í heiminum. Til að rannsaka orsakir pess og leiðir til úrbóta varð til samhentur hópur íslenskra vísindamanna, sem í samvinnu við pekkta sérfræðinga

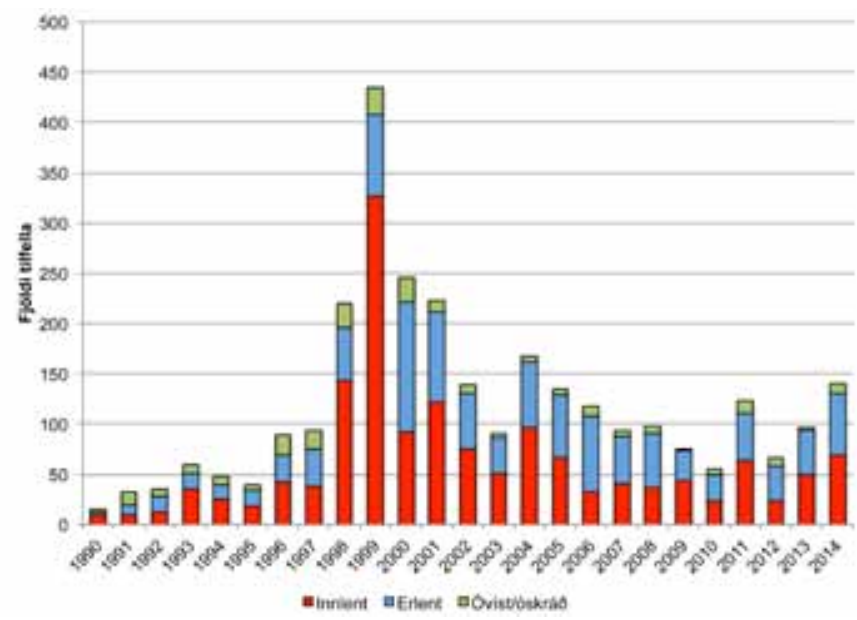

Mynd 1. Nýgengi sýkinga af völdum Campylobacter á Íslandi eftir árum og uppruna (innlendum, erlendum og ópekktum).

á sviði Campylobactersýkinga í Bandaríkjunum, Kanada og innlenda kjúklingaframleiðendur, tókst að lækka nýgengið niður í раð sem pað var fyrir pennan faraldur (mynd 1).

Aðgerðirnar sem gripið var til voru margvíslegar (bætt aðstaða, verkferlar og fræðsla fyrir starfsfólk í matvælaframleiðslu um smitgátarvinnubrögð, lekaheldar neytendaumbúðir og frysting á kjúklingum úr menguðum hópum, svo og fræðsla til almennings). ${ }^{7}$ Árið 2012 gaf Matvælastofnun út nýja áætlun sem fylgir eftir helstu aðgerðunum. Í henni segir: „Afurðum sláturhóps má dreifa óhitameðhöndluðum eða ófrystum pegar fyrir liggja niðurstöður úr eldissýnum viðkomandi sláturhóps um að ekki hafi greinst kampýlóbakter og að sýnið sé ekki eldra en 5 daga gamalt. Ef kampýlóbakter greinist í sýni á eldistímanum eða niðurstöður rannsókna úr eldissýni liggja ekki fyrir eða sýnið er ógilt, pá skulu sláturafurðir viðkomandi alifuglahóps allar frystar eða hitameðhöndlaðar." ${ }^{\prime 8}$ Ástæður pessa eru að frystingin fækkar Campylobacter tíu til púsundfalt og byggir pað meðal annars á íslenskum rannsóknum. ${ }^{9}$

Ekki er vitað til pess að slíkar aðgerðir séu viðhafðar í öðrum löndum pótt vitað sé um gagnsemi peirra, par sem pær auka á kostnað við framleiðslu kjúklinganna. Ekki er hægt að tryggja að kjúklingaafurðir séu Campylobacter-fríar og verður pess vegna að ganga út frá pví að ferskir kjúklingar geti verið mengaðir af Campylobacter, einkum erlendis par sem ekki eru viðhafðar eins strangar aðgerðir og á Íslandi. Erfitt er að bera saman nýgengi Campylobacter- og Salmonellasýkinga á milli landa vegna ólíkra viðhorfa og aðferða við greiningu og skráningu. Pannig benda opinberar upplýsingar til pess að nýgengi Campylobacter- og Salmonellasýkinga sé mun lægra í Suður- og Austur-Evrópu heldur en í Norður-Evrópu og á Norðurlöndunum, pótt raunveruleikinn sé allt annar. ${ }^{10,11}$ Lönd Norður-Evrópu eru mögulega samanburðarhæf, en árið 2008 var nýgengi í Wales 119 tilfelli/100.000 íbúa og árin frá 2005 var nýgengið pað lægsta á Íslandi í samanburði við Danmörk, Finnland, Noreg, Svípjóð og Holland. ${ }^{12,13}$ Í töflu I má sjá nýgengið á Íslandi fyrir árin 2010-2014, ${ }^{14}$ til samanburðar við nýbirt nýgengi í nokkrum löndum Evrópu og í Evrópusambandinu árið 2013. ${ }^{15}$ Í rannsókn á vegum MATÍS og Matvælastofnunar á algengi Campylobacter og Salmonella í ferskum kjúklingaafurðum á Íslandi, 
Tafla I. Nýgengi greindra sýkinga af völdum Campylobacter og Salmonella á Íslandi árin 2010-2014, samanborið við nokkur lönd i Evrópu og í Evrópusambandinu árið 2013; fjöldi/100,000 íbúa.

\begin{tabular}{lcl}
\hline & Campylobacter & Salmonella \\
\hline Ísland & & \\
\hline 2010 & 17,3 & 10,7 \\
\hline 2011 & 38,6 & 17,6 \\
\hline 2012 & 20,6 & 12,5 \\
\hline 2013 & 31,2 & 15,1 \\
\hline 2014 & 43,3 & 12,6 \\
\hline Danmörk & 173,7 & 20,3 \\
\hline Svípjóð & 84,9 & 29,7 \\
\hline Noregur & 65,2 & 26,9 \\
\hline Bretland & 104 & 13,2 \\
\hline Pýskaland & 77,3 & 22,8 \\
\hline EU & 64,8 & 20,4 \\
\hline
\end{tabular}

par sem rannsökuð voru 537 sýni frá maí 2012 til apríl 2013, fundust pessar bakteríur ekki í neinu sýni. Af sömu ástæðu og að ofan greinir er erfitt að bera saman algengi pess að finna Campylobacter í ferskum kjúklingafurðum. Nýjustu gögn um algengi Campylobacter í ferskum tilbúnum kjúklingaafurðum í Evrópu eru frá 2013, en par er algengið að jafnaði $26 \%$, eða allt frá 0\% í Slóvakíu upp í $74 \%$ í Luxemburg (í sumum tilfellum byggt á mjög fáum sýnum). ${ }^{15}$ Staða pessara mála er pví mjög góð hér á landi.

Salmonella spp.

Á Íslandi er nýgengi Salmonellasýkinga 15,2/100.000, næstum pví helmingi lægra en nýgengi Campylobactersýkinga. Fleiri Íslendingar smitast af Salmonella í útlöndum en á Íslandi (mynd 2). Salmonellasýkingar eru pví tiltölulega sjaldgæfar á Íslandi og oftast er um að ræða stök tilfelli sem erfitt er að rekja. Á sama hátt og fyrir Campylobactersýkingar er mjög lítill hluti Salmonellasýkinga greindur og tilkynntur og geta nýgengistölur pví verið mjög villandi og erfitt að bera saman á milli landa. Pannig virðist sem



Mynd 2. Nýgengi sýkinga af völdum Salmonella á Íslandi eftir árum og uppruna (innlendum, erlendum og ópekktum).
Salmonellasýkingar séu mun algengari í Norður- en Suður-Evrópu, pó að raunin sé allt önnur eins og sýnt hefur verið fram á með mælingum á mótefnum gegn Salmonella hjá hópi fólks í 13 löndum Evrópu. ${ }^{10,11}$ Ein stærsta Salmonella-hópsýking sem komið hefur upp á Íslandi var árið 2000 og var rakin til innflutts salats. Par var um fjölónæman $S$. typhimurium stofn að ræða. ${ }^{16}$ Reynsla höfunda er sú að stofnar sem taldir eru vera innlendir hafa alltaf verið mjög næmir fyrir sýklalyfjum, pannig að pegar um fjölónæma stofna er að ræða megi reikna með pví að peir séu upprunnir í útlöndum. Matvæli sem eru upprunnin utan Íslands eru pví ekki aðeins líklegri til að innihalda Salmonella, heldur er Salmonella sem berst frá útlöndum (öðrum en Norðurlöndunum) mun líklegri til að vera ónæm fyrir mörgum sýklalyfjum. Salmonella fannst ekki í innlendum kjúklingaafurðum í nýlegri rannsókn á neytendamarkaði á Íslandi. ${ }^{17}$

Alifuglabændum hefur tekist svo vel upp að fyrirbyggja Campylobacter og Salmonellu smit, að Ísland er orðin fyrirmynd annarra pjóða. Hér á landi er til dæmis brugðist við öllum tegundum Salmonellu, en ekki aðeins S. typhimurium og S. enteritidis eins og krafa er um í Evrópusambandinu..$^{18}$ Finnist einhver Salmonella tegund í eldishópi alifugla hér á landi er óheimilt að senda hann til slátrunar, öllum fuglum í hópnum er fargað og allt urðað. ${ }^{19}$ Finnist Salmonella í sýnum teknum í sláturhúsi hérlendis eru afurðir hópsins innkallaðar og pað sama gildir ef Salmonella finnst á markaði.

Escherichia coli

E. coli er ein af algengustu bakteríunum í pörmum manna og dýra og pannig mikilvægur hluti eðlilegrar örveruflóru peirra. Til eru nokkur afbrigði af E. coli sem geta valdið niðurgangi. Algengastir eru líklega svokallaðir „enterotoxigenic“ E. coli (ETEC), sem eru algengasta orsök ferðamannaniðurgangs. Annað afbrigði sem nefnist „Enterohaemorrhagic“ E. coli (EHEC) getur valdið blóðugum niðurgangi og um $15 \%$ barna innan 10 ára aldurs sem sýkjast fá bráða nýrnabilun (haemolytic uraemic syndrome). Ákveðnar sermisgerðir eru pekktari að pví að valda pessum einkennum en aðrar og er sermisgerðin O157:H7 peirra pekktust og hafa saurræktanir að mestu miðað við að finna pá sermisgerð. Árið 2011 varð stór hópsýking í Pýskalandi af sermisgerðinni O104:H4, sem greindist ekki með hefðbundnum aðferðum. ${ }^{20}$ Við grun um EHEC-sýkingu er pví nú einnig mælt með leit að eiturefnum bakteríunnar í saur í stað leitar að sermisgerð O157:H7 eingöngu. ${ }^{21}$ EHEC er aðallega að finna í meltingarvegi ungra nautgripa, en peir geta líka lifað lengi í umhverfinu og pannig mengað vatn og grænmeti. ${ }^{22}$ EHECsýkingar hafa verið mjög sjaldgæfar á Íslandi, eða að jafnaði aðeins 0-2 tilfelli á ári (mynd 3), pað er nýgengi 0-0,6 tilfelli/100.000 á ári. Til samanburðar er nýgengið í Skotlandi um fjögur tilfelli/100.000 á ári. ${ }^{23}$ Árin 2007 og 2009 skáru sig mjög úr á Íslandi vegna hópsýkinga. Uppruni hópsýkingarinnar árið 2009 hefur enn ekki fundist, en hópsýkingin árið 2007 var vegna mengaðs salats sem var innflutt frá Hollandi. ${ }^{24}$

Líklega má rekja lágt nýgengi á Íslandi til pess að EHEC annaðhvort finnst ekki eða er sjaldgæft í nautgripum á Íslandi. Í nýlegri rannsókn á vegum Matvælastofnunar voru tekin sýni úr 845 nautgripum (169 nautgripabú) í 7 umdæmum til að kanna hvort greina mætti Salmonellu eða E. coli O157:H7 (EHEC) í sýnunum. Öll sýnin 




Mynd 3. Nýgengi sýkinga af völdum EHEC (Enterohaemorrhagic E. coli) á Íslandi eftir árum og uppruna (innlendum, erlendum og ópekktum).

voru neikvæð og ályktað að litlar líkur væru á pví að EHEC og Salmonella berist í fólk með íslenskum nautgripaafurðum. ${ }^{25} \mathrm{Ný}$ óbirt rannsókn sem annar höfunda er aðili að (FG), hefur pó sýnt fram á tilvist tiltekinna erfðaefna pessara baktería í kúamykju, kindaspörðum, nautahakki og frárennslissýnum, en pýðing pess er enn óviss.

\section{Sýklalyfjaónæmi}

Samkvæmt nýlegum skýrslum frá Evrópsku sóttvarnarstofnuninni (European Centre for Disease Control and Prevention) og Alpjóðaheilbrigðisstofnuninni (World Health Organisation) er sýklalyfjaónæmi ein stærsta ógnin við lýðheilsu í heiminum í dag. Jafnframt er pað talið meðal stærri ógnana við efnhagslegan stöðugleika í heiminum. ${ }^{26-28}$ Mikilvægt er að sporna eins og hægt er við vexti sýklalyfjaónæmis.

Á Íslandi hefur notkun sýklalyfja hjá mönnum utan sjúkrahúsa verið nokkuð meiri en á hinum Norðurlöndunum, en minni

Tafla II. Hlutfall stofna (prósent) með minnkað næmi eftir pví hvort smitið taldist af innlendum eða erlendum uppruna, síðastliðin 5 ár, ásamt fjölda næmisprófaðra stofna.

\begin{tabular}{|c|c|c|c|c|c|}
\hline & \multicolumn{3}{|c|}{ Campylobacter } & \multicolumn{2}{|c|}{ Salmonella } \\
\hline & Erýprómýsín & Ciprofloxasín & $\begin{array}{l}\text { Fjöldi } \\
\text { stofna }\end{array}$ & Ciprofloxasín & $\begin{array}{l}\text { Fjöldi } \\
\text { stofna }\end{array}$ \\
\hline \multicolumn{6}{|c|}{ Innlent smit } \\
\hline 2010 & 0 & 0 & 24 & 0 & 13 \\
\hline 2011 & 0 & 26 & 62 & 0 & 24 \\
\hline 2012 & 0 & 29 & 24 & 0 & 17 \\
\hline 2013 & 0 & 6 & 50 & 0 & 13 \\
\hline 2014 & 0 & 6 & 69 & 0 & 13 \\
\hline \multicolumn{6}{|c|}{ Erlent smit } \\
\hline 2010 & 8 & 75 & 24 & 0 & 18 \\
\hline 2011 & 2 & 73 & 44 & 11 & 27 \\
\hline 2012 & 3 & 76 & 33 & 0 & 16 \\
\hline 2013 & 2 & 88 & 41 & 6 & 32 \\
\hline 2014 & 10 & 80 & 61 & 29 & 24 \\
\hline
\end{tabular}

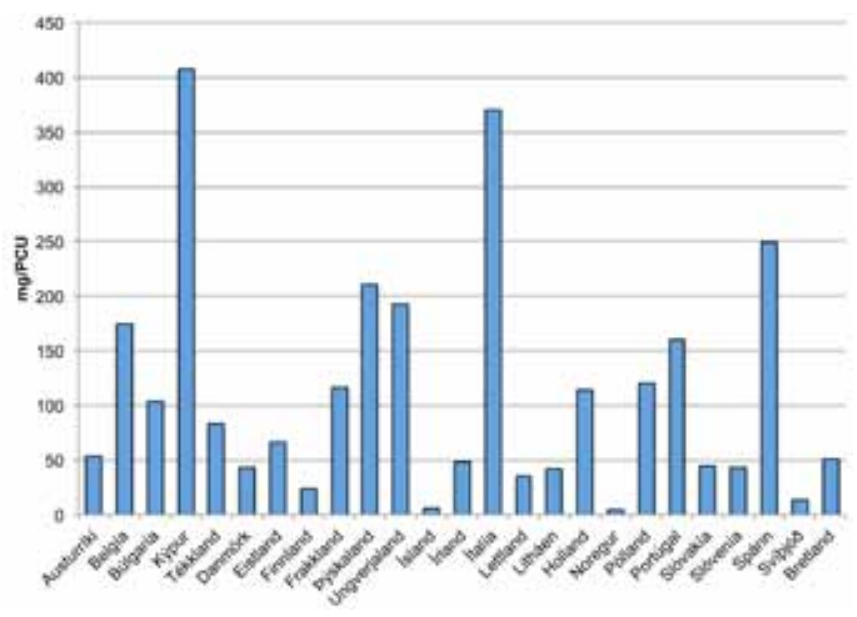

Mynd 4. Notkun sýklalyfja í dýrum í 25 Evrópulöndum árið 2011 mælt í mg/PCU (PCU, population correction unit, notað til að áætla sýklalyfjanotkun eftir pyngd búfénaðar og sláturdýra til manneldis). ${ }^{21}$

á sjúkrahúsum..$^{29,30}$ Sýklalyfjanotkun er pó mun meiri í Suður-Evrópu en í Norður-Evrópu. ${ }^{31}$ Í mörgum löndum er sýklalyfjanotkun mun meiri hjá dýrum en mönnum og í heildina er meira notað af sýklalyfjum í landbúnaði. Í nýlegri skýrslu frá EMA (European Medicines Agency) kemur fram að sýklalyfjanotkun í dýrum á Íslandi sé með pví allra lægsta sem pekkist í Evrópu (mynd 4), auk pess sem nánast ekkert er notað af mikilvægustu mannasýklalyfjunum í íslenskum landbúnaði. ${ }^{32}$ Í nýlegri skýrslu er sýnt fram á sterka fylgni á milli sýklalyfjanotkunar í dýrum og sýklalyfjaónæmis í dýrum í Evrópu. ${ }^{33}$ Pað ætti pví ekki að koma á óvart að sýklalyfjaónæmi í bakteríum sem ræktast frá dýrum á Íslandi væri mjög lítið. Pví miður eru ekki gerð regluleg næmispróf á svokölluðum bendibakteríum (indicator bacteria, til dæmis E. coli) frá dýrum á Íslandi. ${ }^{30}$ Hins vegar er hægt að leiða líkur að pví að sýklalyfjaónæmi í dýrum á Íslandi sé lægra en í öðrum löndum. Ef sýklalyfjanæmi Salmonella og Campylobacter sem ræktast frá sýkingum í mönnum er skoðað eftir pví hvort um innlent eða erlent smit er að ræða, eru erlendu stofnarnir ónæmari en peir innlendu. ${ }^{34}$ Síðastliðin fimm ár (2010-2014) var innlend Salmonella alltaf næm fyrir ciprofloxasíni en 0-29\% erlendra stofna ónæmir. Sambærilegar tölur fyrir Campylobacter voru 0-29\% fyrir innlenda stofna en $75-88 \%$ fyrir erlenda stofna. Innlendir Campylobacter-stofnar voru alltaf næmir fyrir erýprómýsíni, en 2-10\% erlendu stofnanna ónæmir (sjá töflu II). ${ }^{34}$ Ónæmi hefur líka verið kannað hjá Salmonella-stofnum ræktuðum frá kjúklingum og svínum og Campylobacter-stofnum ræktuðum frá kjúklingum, og reyndist vera lágt og sambærilegt við pað sem sést á hinum Norðurlöndunum en lægra en í öðrum löndum Evrópu. ${ }^{35,36}$ Í nýrri skýrslu sóttvarnalæknis um sýklalyfjanotkun og sýklalyfjanæmi baktería í mönnum og dýrum á Íslandi fyrir árið 2013 kemur fram að árið 2013 hafi fyrst verið farið að skoða sýklalyfjanæmi Campylobacter-stofna sem ræktast frá alifuglum. ${ }^{30}$ Prófaðir voru 16 af peim 17 stofnum sem greindust og voru allir næmir fyrir erýprómýsíni og ciprofloxasíni.

Í Evrópu gilda strangari reglur um notkun sýklalyfja í landbúnaði en annars staðar í heiminum, en par var sýklalyfjanotkun til vaxtarörvunar bönnuð í janúar 2006. Með tilkomu verksmiðjubúa og tilheyrandi streitu, prengslum og óhreinindum í umhverfi dýra hefur sýklalyfjanotkunin aukist í landbúnaði. Sýklalyfin 
eru pá ekki eingöngu notuð til að meðhöndla og koma í veg fyrir sýkingar, heldur er peim einnig blandað í fóður til að örva vöxt dýranna. Sýklalyfjaónæmi próast hratt við pessar aðstæður á búunum og í umhverfi peirra. En sýklalyfjaónæmið berst einnig víðar frá peim. Eitt af meginvandamálum við verksmiðjubú er hið mikla magn saurs sem kemur frá dýrunum og parf að losa sig við, og er pá gjarnan notaður sem áburður á ræktarland. Sem dæmi má nefna að um 70 milljón tonnum af lífrænum áburði er dreift árlega á ræktað land í Bretlandi einu. ${ }^{37}$ Ræktað land og pað sem verið er að rækta mengast pannig með áburðinum af sýklalyfjum og sýklalyfjaónæmum bakteríum sem geta síðan borist áfram í grunnvatnið og jafnvel mengað vatnsból. Á pennan hátt getur grænmeti, baunaspírur og ber mengast og síðan smitað menn sem oftast borða pessar vörur ferskar. ${ }^{38,39}$

\section{Methisillínónæmir Staphylococcus aureus (MÓSA, enska MRSA)}

Staphylococcus aureus er einn af mikilvægustu sýkingarvöldum í mönnum og getur valdið fjölbreyttum sýkingum. MÓSAr eru ónæmir fyrir öllum lyfjum í flokki beta-laktam sýklalyfja og oft einnig fyrir öðrum sýklalyfjaflokkum. Petta gerir meðferð mun erfiðari. MÓSAr hafa verið mun sjaldgæfari í mönnum á Íslandi en í flestum öðrum Evrópulöndum. ${ }^{40}$ Á Íslandi er leitað að peim með kerfisbundnum hætti hjá sjúklingum sem hafa dvalið á erlendu sjúkrahúsi innan 6 mánaða og leggjast inn á sjúkrahús. Ekki er fylgst beint með næmi stafýlókokka hjá dýrum eða matvælum á Íslandi, en eftirlit er með næmi Staphylococcus aureus pegar bakterían ræktast frá nautgripum með júgurbólgu (bovine mastitis). Peir $S$. aureus stofnar sem hafa ræktast í eftirliti Matvælastofnunar með júgurbólgu hafa alltaf verið næmir fyrir methisillíni. ${ }^{41}$

Á undanförnum árum hafa MÓSAr fundist í búfénaði í nokkrum löndum og geta peir borist frá peim til manna. ${ }^{42}$ Í Pýskalandi hafa menn miklar áhyggjur af útbreiðslu MÓSA í svínum, nautgripum og kjúklingum par sem peir eru nú pegar farnir að valda sýkingum í mönnum. Smitleiðin er talin vera með beinni snertingu, mengun í umhverfi og neyslu á menguðu kjöti. ${ }^{43}$ Sýnt hefur verið fram á pað með óyggjandi hætti að pað eru raunverulegir dýra MÓSA stofnar sem geta borist í menn og sýkt pá. ${ }^{44}$ Árið 2007 virtust tilteknir dýra MÓSA stofnar vera algengastir í Hollandi, Belgíu, Danmörku og Austurríki. ${ }^{45}$ Í Hollandi voru MÓSAr algengari í fólki á svæðum par sem svínarækt var mest og í Pennsylvaníu í Bandaríkjunum var hærri tíðni MÓSA í fólki sem bjó á svæðum par sem svínasaur var dreift á ræktað land. ${ }^{46,47}$

\section{Gram-neikvæðar stafbakteriur}

Gram-neikvæðir stafir af ætt Enterobacteriaceae eru flestir hluti af eðlilegri parmaflóru manna og dýra og sumir pekktir sýkingarvaldar eins og Salmonella og Shigella. Ein mikilvægasta tegundin í pessum flokki er E. coli. Sýklalyfjaónæmi hjá pessum bakteríum tengist oftast svokölluðum beta-laktamösum, ensímum sem brjóta niður beta-laktam sýklalyfin. Karbapenemasar eru breiðrófs-ensím sem geta eyðilagt öll sýklalyf í flokki beta-laktam sýklalyfja og hafa verið að breiðast út um heiminn, einkum með bakteríunni Klebsiella pneumoniae. Pví miður fylgir pessu oft ónæmi fyrir öðrum sýklalyfjaflokkum og eru nú að breiðast út um heiminn stofn- ar ónæmir fyrir öllum sýklalyfjum. Pað er pví mikið áhyggjuefni að árið 2009 fannst karbapenemasi í fyrsta sinn á plasmíði, bæði í E. coli og Klebsiella pneumoniae í sænskum sjúklingi nýkomnum frá Indlandi. ${ }^{48}$ Plasmíð geta auðveldlega flust á milli baktería í ætt Enterobacteriaceae og er pessi próun pví mikið áhyggjuefni. Frekari rannsóknir á Indlandi hafa svo sýnt að slíkar ofurbakteríur er víða að finna í grunnvatni og neysluvatni og er áætlað аð аð minnsta kosti 100 milljónir Indverja beri pessa bakteríu í pörmunum. ${ }^{49,50}$ pessar bakteríur hafa einnig náð fótfestu víðar, meðal annars í Grikklandi og Ítalíu. ${ }^{51}$ Mikilvægt er að koma í veg fyrir að pessar bakteríur berist til Íslands og nái par fótfestu. Pær gætu borist með sjúklingum sem eru að koma af erlendum sjúkrahúsum, ferðamönnum, matvælum og dýrafóðri. Á sjúkrahúsum á öllum Norðurlöndunum er nú skimað fyrir pessum fjölónæmu bakteríum hjá sjúklingum sem hafa veriðá sjúkrahúsum par sem karbapenemasamyndandi bakteríur gæti verið að finna. Ferðamenn frá svæðum par sem pessar bakteríur eru algengar gætu einnig auðveldlega óafvitandi borið pessar bakteríur og aukast líkurnar mjög ef peir hafa tekið inn sýklalyf á ferðalaginu og/eða fengið ferðamannaniðurgang. ${ }^{52}$ E. coli getur auðveldlega borist með matvælum og dýrafóðri og er pað áhyggjuefni að menguð matvæli geti flýtt fyrir útbreiðslu pessara fjölónæmu baktería um heiminn. ${ }^{39}$ Í drögum að nýrri aðgerðaráætlun Alpjóðaheilbrigðisstofnunarinnar er meðal annars lögð áhersla á mikilvægi matvæla og umhverfis í dreifingu á fjölónæmum bakteríum. ${ }^{53}$ Nýlega fannst karbapenemasa-myndandi stafbaktería í smokkfiski í verslun í Kanada. Smokkfiskurinn hafði verið fluttur inn frá Suður-Kóreu. ${ }^{54}$ Petta sýnir að mikilvægt er að fylgjast með sýklalyfjanónæmi í matvælum eins og reyndar er farið að gera á hinum Norðurlöndunum.

Sýklalyfjamengun í landbúnaði og umhverfi er vandamál í flestum péttbýlum löndum, einkum par sem eftirlit með sýklalyfjanotkun er lítil sem engin. •að er áhyggjuefni að sum sýklalyf brotna mjög hægt niður í náttúrunni og pví má ætla að sýklalyfjaónæmi tengt umhverfi og landbúnaði eigi eftir að verða mun meira vandamál í framtíðinni. ${ }^{55}$

\section{pýđing fyrir Ísland}

Hærri tíðni Campylobacter, Salmonella og EHEC í dýrum og matvælum utan Íslands pýðir að meiri líkur eru á pví að smitast af pessum sýklum með neyslu innfluttra en innlendra ferskra matvæla. Hvað Campylobacter og Salmonella varðar er áhættan aðallega tengd kjúklingum og verður að gera ráo fyrir hærra nýgengi Campylobactersýkinga í mönnum á Íslandi ef neysla á ferskum influttum alifuglaafurðum eykst. Hærra nýgengi leiðir af sér kostnað vegna fleiri veikra einstaklinga með tilheyrandi vinnutapi og á stundum sjúkrahúsinnlögnum. Aðaláhyggjuefnið er pó ekki hærra nýgengi Campylobactersýkinga, heldur innflutningur og útbreiðsla á Gram-neikvæðum stafbakteríum sem eru ónæmar fyrir flestum eða öllum sýklalyfjum. Erfitt getur verið að rekja uppruna innfluttra matvæla og fóðurs sem getur verið upprunnið utan Evrópu pótt pað sé flutt inn frá öðru Evrópulandi. Fersk matvæli eins og grænmeti og kjöt geta borið fjölónæmar bakteríur. Ekki má gleyma dýrafóðri, en árið 2011 voru flutt inn yfir 83.000 tonn af dýrafóðri, par af um 2000 tonn fyrir alifugla. ${ }^{56}$ Reynslan hefur pegar sýnt fram á áhættu af pessum innflutningi. Á árinu 2013 greindist 
Salmonella tvívegis í hitameðhöndluðu fóðri, annars vegar fóðri sem ætlað er kjúklingum og hins vegar í húsdýrafóðri. ${ }^{59,60}$ Annaðhvort hefur hitameðhöndlunin verið ófullnægjandi eða að fóðrið hefur mengast eftir hitameðhöndlun. Petta undirstrikar mikilvægi pess að vera meðvitaður um áhættuna sem fylgir innfluttu fóðri og mikilvægi réttrar hitameðhöndlunar á pví.

Mjög lítil notkun sýklalyfja í íslenskum landbúnaði ásamt virkum aðhaldsaðgerðum til að draga úr útbreiðslu Campylobacter og Salmonella hafa gert íslensk matvæli með peim öruggustu í heiminum í dag. Mikilvægt er að almenningur sé meðvitaður um petta. Engin matvæli eru 100\% örugg, en með pví að pekkja upprunaland matvæla geta neytendur tekið upplýstari ákvörðun við kaup á matvælum.

\section{Pakkarord}

Höfundar pakka Hjördísi Harðardóttur, sérfræðilækni á sýklafræðideild Landspítala, fyrir yfirlestur á greininni og góðar ábendingar.

\section{Heimildir}

1. Rossi J, Garner SA. Industrial Farm Animal Production: A Comprehensive Moral Critique. J Agr Environ Ethic 2014 27: 479-522.

2. Marshall BM, Levy SB. Food animals and antimicrobials impacts on human health. Clin Microbiol Rev 2011; 24 718-33.

3. Ercsey-Ravasz M, Toroczkai Z, Lakner Z, Baranyi J Complexity of the international agro-food trade network and its impact on food safety. PloS one 2012; 7: e37810.

4. Taylor LH, Latham SM, Woolhouse ME. Risk factors for human disease emergence. Philos Trans R Soc Lond B Biol Sci 2001 : 356: 983-9.

5. Cleaveland S, Laurenson MK, Taylor LH. Diseases of humans and their domestic mammals: pathogen characteristics, host range and the risk of emergence.Philos Trans R Soc Lond B Biol Sci 2001; 356: 991-9.

6. Horrocks SM, Anderson RC, Nisbet DJ, Ricke SC Incidence and ecology of Campylobacter jejuni and coli in animals. Anaerobe 2009; 15: 18-25.

7. Tustin J, Laberge K, Michel P, Reiersen J, Daðadóttir S, Briem $\mathrm{H}$, et al. A national epidemic of campylobacteriosis in Iceland, lessons learned. Zoonoses Public Health 2011; 58: $440-7$.

8. Matvælastofnun. Eftirlit með kampýlóbakter í alifuglum. Sýnatökur í frumframleiðslu og slátrun og viðbrögð. In MAST, editor. MAST, Selfossi 2012: 8 .

9. Georgsson F, Thorkelsson AE, Geirsdottir M, Reiersen J, Stern NJ. The influence of freezing and duration of storage on Campylobacter and indicator bacteria in broiler carcasses. Food Microbiol 2006; 23: 677-83.

10. Majowicz SE, Musto J, Scallan E, Angulo FJ, Kirk M O'Brien SJ, et al. The global burden of nontyphoida Salmonella gastroenteritis. Clin Infect Dis 2010; 50: 882-9.

11. Falkenhorst G, Simonsen J, Ceper TH, van Pelt W, de Valk $\mathrm{H}$, Sadkowska-Todys M, et al. Serological cross-sectional studies on salmonella incidence in eight European countries: no correlation with incidence of reported cases. BMC Public Health 2012; 12: 523.

12. Janiec J, Evans MR, Thomas DR, Davies GH, Lewis H Laboratory-based surveillance of Campylobacter and Salmonella infection and the importance of denominator data. Epidemiol Infect 2012; 140: 2045-52.

13. Jore $\mathrm{S}$, Viljugrein $\mathrm{H}$, Brun $\mathrm{E}$, Heier BT, Borck B, Ethelber $\mathrm{S}$, et al. Trends in Campylobacter incidence in broilers and humans in six European countries, 1997-2007. Prev Vet Med 2010; 93: 33-41.

14. Landspítali Sýklafræðideild. landspitali.is/library/Sameiginlegar-skrar/Gagnasafn/Klinisk-svid-og-deildir/ Rannsoknarsvid/Syklafraedideild/Salm-Camp-E-coliO157-VTEC-2014.pdf - maí 2015.

15. EFSA/ECDC. The European Union summary report on trends and sources of zoonoses, zoonotic agents and foodborne outbreaks in 2013. EFSA J 2015; 13 .

16. Crook PD, Aguilera JF, Threlfall EJ, O'Brien SJ, Sigmundsdóttir G, Wilson D, et al. A European outbreak of Salmonella enterica serotype Typhimurium definitive phage type 204b in 2000. Clin Microbiol Infect 2003; 9: 83945 .

17. Reynisson E, Marteinsson VT, Georgsson F. Rannsókn á algengi Salmonella og Campylobacter í íslenskum kjúklingaafurðum á neytendamarkaði. Matís, Reykjavík 2013.
18. European Commission. Commission regulation concerning a Union target for the reduction of Salmonella enteritidis and Salmonella typhimurium in flocks of broilers, as provided for in Regultion (EC) No 2160/2003 of the European Parliament and of the Council. In: Commission E, editor. Framkvæmdastiórn ESB, Brussel 2012.

19. Sjávarútvegs-/Landbúnaðarráðuneytið. Reglugerð um (3.) breytingu á reglugerð nr. 260/1980, um útbúnað alifuglasláturhúsa, slátrun alifugla, verkun peirra og heilbrigðisskoðun. Sjávarútvegs-/Landbúnaðarráðuneytið, Reykjavík 2011.

20. Buchholz U, Bernard $H$, Werber D, Böhmer MM, Remschmidt C, Wilking H, et al. German outbreak of Escherichia coli O104:H4 associated with sprouts. N Engl J Med 2011; 365: 1763-70.

21. Ong KL, Apostal M, Comstock N, Hurd S, Webb TH, Mickelson S, et al. Strategies for surveillance of pediatric hemolytic uremic syndrome: Foodborne Diseases Active Surveillance Network (FoodNet), 2000-2007. Clin Infect Dis 2012; 54 Suppl 5: S424-31.

22. Gyles CL. Shiga toxin-producing Escherichia coli: an overview. J Animal Sci 2007; 85(13 Suppl): E45-62.

23. Pennington H. Escherichia coli O157. Lancet 2010; 376: 1428-35.

24. Friesema I, Sigmundsdottir $G$, van der Zwaluw $K$ Heuvelink A, Schimmer B, de Jager C, et al. An international outbreak of Shiga toxin-producing Escherichia coli O157 infection due to lettuce, September-October 2007. Euro Surveill 2008; 13.

25. Konradsson K, Arnthorsdottir Al, Olafsson Th. Rannsókn á E. coli og salmonellu í nautgripum á Íslandi. MAST, Selfossi 2011.

26. The dangers of hubris on human health. Global Risks 2013, Eighth Edition. World Economic Forum, 2013.

27. WHO. Antimicrobial resistance: global report on surveillance 2014. Alpjóðaheilbrigðisstofnunin, Genf 2014

28. ECDC/EMEA. The bacterial challenge: time to react European Centre for Disease Prevention and Control, Stokkhólmi 2009.

29. Simonsen GS, Småbrekke L, Monnet DL, Sørensen TL, Møller JK, Kristinsson KG, et al. Prevalence of resistance to ampicillin, gentamicin and vancomycin in Enterococcus faecalis and Enterococcus faecium isolates from clinical specimens and use of antimicrobials in five Nordic hospitals. J Antimicrob Chemother 2003; 51: 323-31.

30. Sóttvarnalæknir. Sýklalyfjanotkun og sýklalyfjanæmi baktería í mönnum og dýrum á Íslandi 2013. Embætti landlæknis, Reykjavík 2014.

31. Control ECfDPa. Antimicrobial consumption rates by country. 2013. ecdc.europa.eu/en/healthtopics/antimicrobial_resistance/esac-net-database/ - nóvember 2013.

32. Sales of veterinary antimicrobial agents in 18EU/EEA countries in 2010: European Medicines Agency, 2012.

33. Ecdc/Efsa/Ema. ECDC/EFSA/EMA first joint report on the integrated analysis of the consumption of antimicrobial agents and occurrence of antimicrobial resistance in bacteria from humans and food-producing animals. EFSA J 2015; 13

34. landspitali.is/sjuklingar-adstandendur/klinisk-svid-ogdeildir/rannsoknarsvid/syklafraedideild/naemisprof/> maí 2015
35. Thorsteinsdottir TR, Kristinsson KG, Gunnarsson E. Antimicrobial resistance and serotype distribution among Salmonella spp. in pigs and poultry in Iceland, 2001-2005. Microb Drug Resist 2007; 13: 295-300.

36. Thorsteinsdottir TR, Kristinsson KG, Fridriksdottir V, Gunnarsson E. Antimicrobial resistance of Campylobacter spp. isolated from broiler flocks in Iceland 2001-2005. Microb Drug Resist 2008; 14: 49-53.

37. Hutchison ML, Walters LD, Moore A, Crookes KM, Avery SM. Effect of length of time before incorporation on survival of pathogenic bacteria present in livestock wastes applied to agricultural soil. Appl Environ Microbiol 2004; 70: 5111-8.

38. Wellington EMH, Boxall $\mathrm{AB}$, Cross $\mathrm{P}$, Feil EJ, Gaze WH, Hawkey PM, et al. The role of the natural environment in the emergence of antibiotic resistance in gram-negative bacteria. Lancet Infect Dis 2013; 13: 155-65.

39. Woodford N, Wareham DW, Guerra B, Teale C. Carbapenemase-producing Enterobacteriaceae and nonEnterobacteriaceae from animals and the environment: an emerging public health risk of our own making? J Antimicrob Chemother 2014; 69: 287-91.

40. Antimicrobial resistance surveillance in Europe 2011. European Centre for Disease Prevention and Control, Stokkhólmi 2012.

41. De Oliveira AP, Watts JL, Salmon SA, Aarestrup FM. Antimicrobial susceptibility of Staphylococcus aureus isolated from bovine mastitis in Europe and the United States. J Dairy Sci 2000; 83: 855-62.

42. Kuehn B. MRSA may move from livestock to humans. JAMA 2012; 308: 1726

43. Köck R, Schaumburg F, Mellmann A, Köksal M, Jurke A, Becker $\mathrm{K}$, et al. Livestock-associated methicillin-resistant Staphylococcus aureus (MRSA) as causes of human infection and colonization in Germany. PloS one 2013; 8(2): e55040.

44. Harrison EM, Paterson GK, Holden MT, Larsen J, Stegger $\mathrm{M}$, Larsen AR, et al. Whole genome sequencing identifies zoonotic transmission of MRSA isolates with the novel mecA homologue mecC. EMBO Mol Med 2013; 5: 509-15.

45. van Cleef BA, Monnet DL, Voss A, Krziwanek K, Allerberger F, Struelens M, et al. Livestock-associated methicillin-resistant Staphylococcus aureus in humans, Europe. Emerg Infect Dis 2011; 17: 502-5.

46. van Rijen MML, Bosch T, Verkade EJM, Schouls L, Kluytmans JAJW. Livestock-Associated MRSA Carriage in Patients without Direct Contact with Livestock. PloS one 2014; 9: e100294.

47. Casey JA, Curriero FC, Cosgrove SE, Nachman KE, Schwartz BS. High-density livestock operations, crop field application of manure, and risk of community-associated methicillin-resistant Staphylococcus aureus infection in Pennsylvania. JAMA 2013; 173: 1980-90.

48. Yong D, Toleman MA, Giske CG, et al. Characterization of a new metallo-beta-lactamase gene, bla(NDM-1), and a novel erythromycin esterase gene carried on a unique genetic structure in Klebsiella pneumoniae sequence type 14 from India. Antimicrob Ag Chemother 2009; 53: 504654. 
49. Walsh TR, Toleman MA. The emergence of pan-resistant Gram-negative pathogens merits a rapid global political response. J Antimicrob Chemother 2012; 67: 1-3.

50. Walsh TR, Weeks J, Livermore DM, Toleman MA Dissemination of NDM-1 positive bacteria in the New Delhi environment and its implications for human health an environmental point prevalence study. Lancet Infect Dis 2011; 11: 355-62.

51. Canton R, Akova M, Carmeli Y, Giske CG, Glupczynski $\mathrm{Y}$, Gniadkowski M, et al. Rapid evolution and spread of carbapenemases among Enterobacteriaceae in Europe. Clin Microb Infect 2012; 18: 413-31.

52. Kantele A, Laaveri T, Mero S, Vilkman K, Pakkanen SH, Ollgren J, et al. Antimicrobials increase travelers' risk of colonization by extended-spectrum betalactamase-producing Enterobacteriaceae. Clin Infect Dis 2015; 60: 837-46.
53. WHO. Antimicrobial resistance. Draft global action plan on antimicrobial resistance. Albjóðaheilbrigðisstofnunin Genf 2015.

54. Rubin JE, Ekanayake S, Fernando C. Carbapenemaseproducing organism in food, 2014. Emerg Infect Dis 2014; 20: $1264-5$.

55. Woodford N, Wareham DW, Guerra B, Teale C Carbapenemase-producing Enterobacteriaceae and nonEnterobacteriaceae from animals and the environment: an emerging public health risk of our own making? J Antimicrob Chemother 2014; 69: 287-91.

56. Matvælastofnun. Starfsskýrsla 2011. 2012. mast.is/matvaelastofnun/utgafa/skyrslur/ - maí 2015.

57. Thorsteinsdottir TR, Haraldsson G, Fridriksdottir V Kristinsson KG, Gunnarsson E. Prevalence and genetic relatedness of antimicrobial-resistant Escherichia coli isolated from animals, foods and humans in Iceland. Zoonoses Public Health 2010; 57: 189-96.
58. Thorsteinsdottir TR, Haraldsson G, Fridriksdottir V, Kristinsson KG, Gunnarsson E. Broiler chickens as source of human fluoroquinolone-resistant Escherichia coli, Iceland. Emerg Infect Dis 2010; 16: 133-5.

59. Matvælastofnun. Salmonella í hitameðhöndluðu fóðri. mast.is/frettaflokkar/frett/2013/01/30/Salmonella-ihitamedhondludu-fodri/ - maí 2013

60. Matvælastofnun. Grunur um salmonellusmit í húsdýrafóðri. 2013. mast.is/frettaflokkar/frett/2013/09/06/ Grunur-um-salmonellusmit-i-husdyrafodri/ - nóvember 2013.

\section{ENGLISH SUMMARY}

\section{Infection risks associated with importation of fresh food in Iceland}

Karl G. Kristinsson ${ }^{1,2}$, Franklín Georgsson ${ }^{2,3}$

Access to safe food is a privilege for people living in Iceland. Rapid increase in antimicrobial resistance, related to factory farming and antimicrobial use in agriculture, is a major threat to public health. Increasing food trade between countries and continents facilitates global spread of pathogens and resistance. Icelandic agriculture has benefitted from its isolation and small size.

After interventions to reduce the prevalence of Campylobacter and Salmonella at poultry farms, the incidence of human campylobacteriolsis is $17-43 / 100.000$, of which about half is domestically acquired and Salmonella infections 10-15/100.000 mainly acquired abroad. Since Enterohaemorrhagic E. coli (EHEC) has not been detected in domestic cattle, the low incidence of infections is not surprising (0-0.6/100.000/ year). A recent outbreak due to a multiresistant EHEC strain was traced to imported lettuce. Antimicrobial use in Icelandic agriculture is among the lowest in Europe and domestic infections caused by Salmonella and Campylobacter are rarely caused by resistant strains. Carbapenemase producing Enterobacteriaceae have not been found in Iceland.

Low use of antimicrobials in Icelandic agriculture and actions to limit the spread of Campylobacter and Salmonella have been successful. The public should be informed of the importance of the origin of food and that Icelandic food products are among the safest.

${ }^{1}$ Department of Clinical Microbiology, Landspitali University Hospital, ${ }^{2}$ University of Iceland, ${ }^{3} \mathrm{MATi} S$.

Key words: Fresh food, food transportation, infection risk, antibacterial resistance, antimicrobial resistance, Iceland

Correspondence: Karl G. Kristinsson, karl@landspitali.is 